\title{
The Law Enforcement Dilemma on Illegal Mining in South Kalimantan
}

\author{
Endah Labati Silapurna \\ Student of Doctoral Program of Legal Sciences \\ University of Borobudur \\ Jakarta, Indonesia \\ endahlabaty2004@gmail.com
}

\begin{abstract}
The existence of the mining sector such as coal mining for example, as one of the nonrenewable resources is needed to support mining activities. The mining sector located along the Meratus mountains in the forests of Borneo on one hand has economic benefits, but on the other it can cause various environmental problems, including: bad environment for health, degradation of human resources quality, destruction of infrastructure such as the loss of tribal land rights, destruction of smallholder plantations, poverty, major causes of flooding/erosion and other unsustainable environmental problems.
\end{abstract}

New coal mines in South Kalimantan are seen not to reflect the implementation of progressive environmental law and there is no legal awareness about the reclamation of coal mines. There has also been no monitoring from the government to ensure the implementation of post-coal mining reclamation. They only take advantage of the regional aspects of Law No. 4 of 2009 on Mineral and Coal without linking to Law based on Environmental Management, such as Law No. 32 Year of 2009, Law No. 26 Year of 2007 on Spatial Planning, Law No. 5 Year of 1990 on Conservation of Resources Natural Resources and Ecosystems and Law No. 41 of 1999 on Forestry.

Law No. 44 of 2009 on Minerals and Coal is still felt not yet sided with the small people. The negative impact is felt in the environment and society. To that end, Law No. 4 Year 2009 should be understood substantively and progressively for the purpose of the prosperity of the community without damaging the environment. The legal function in the field of environmental conservation is as a social engineer. In this field, it is expected to create a behavior oriented towards the preservation of the environment, biological natural resources and its ecosystem for the benefit of present and future generations. Based on Law No. 44 of 2009 on Mineral and Coal Mining, it places reclamation as one of the obligations of mining license holders.

\section{Keywords - legal aspect, coal mining, reclamation}

\section{INTRODUCTION}

Indonesia's natural wealth is famous for its abundance. Forests are extensive, the soil is fertile, the landscape is very beautiful. The area of the waters is very wide with a very large commodity fish playing an important role in human life [1]. Not only that, there are various forms of mining of minerals in the form of gold, nickel, tin, copper, coal and so on. But seeing the fact that there is a rich natural resources that do not provide a benefit for the people of Indonesia, especially in terms of mining industry. It is very contradictory to the mission as stipulated in the 1945 Constitution, insists that Indonesia's natural wealth should be managed and used sustainably for the welfare of Indonesia and mankind in general for now and in the future [2].

Mining is a complex business activity, capital-intensive, risk-laden and involves high technology. Therefore, the management of mines must manage them wisely. So that mining activities should pay attention to various important aspects, both technical and non technical, such as: socioeconomic as pects of culture, environment and conservation of mining commodities. Mining law is the whole legal norm governing the authority of the state in the management of minerals and regulating the legal relationship between the State and the person or legal entity in the management of the utilization of minerals. The mining licensing system refers to the Ministerial Regulation No. 34 of 2017 on Licensing in the Field of Mineral Mining and this is a revision of the previous Regulation which is made to facilitate the reporting systemfor mining license (IUP) or Work Agreement on Coal Mining Concession (PKP 2B) and mining guarantee business license (IUJP) Permit holder especially in the RKAB (Work Plan of Cost Budget) Reporting System each year.

The existence sector coal mining is urgently needed to support development. The mining sector is contributing economically to the local level. This is one of the natural resources that is not renewable (Unrenewable Resources). So that mining can last for a long time, the utilization should be done wisely and planned, so it can be passed on to the future generations.

Mine is the most important source of earth that must be given special attention by human beings, considering how precious the goods are in the eyes of the world.

Indonesia is a country which is rich in mines [3]. According to the annual survey of PWC (PriceWaterhouse Coopers), mining products exports contributes 2 percent of total exports since 2002, while the sector also contributes $2.7 \%$ of gross domestic product (GDP) and US \$ 920 million in taxes and non-tax levies for different levels of government. The Mining Sector also provides substantial employment, whether directly involved and in the production process as well as in various mining support products and services [4].

If mining activities are not properly implemented may result in negative environmental impacts, especially significant disturbance of the soil surface balance, requiring significant energy, thought and costs for the recovery process. 
Environmental impacts due to mining activities include: decreasing land productivity, increasing soil packing, erosion and sedimentation, soil or landslide movement, disruption of flora and fauna, dis ruption of coal mining health. In addition, mining activities caused damage to several areas of mangrove forest and swamp, mangrove palm forest and area's fish and shrimp catch as one of the sources of community life. Mining is often conducted traditionally by local communities with business actors who are not complemented with equipment facilities, knowledge and capital. In addition to these limitations, the regulatory constraints also exacerbate the situation and conditions, so mining is likely to be undertaken without permission (PETI), making it vulnerable to accidents and workplace safety violations and sometimes causing pollution and uncontrolled environmental damage.

Damage from disturbances caused by PETI activities in general is very disturbing to the wider community life. The destruction of land, forest and plantations caused by illegal logging activities by PETI without being followed by reclamation efforts, raises various problems that are very detrimental to the public interest and pose a burden to the Regional Government.

PETI activities undermine the position, rights and responsibilities of coal contractors. The coal contractor shall be solely responsible for all matters connected to its operations. Illegally operated PETI in the contract area does not pay attention to what the coal contractor is responsible for and is not responsible for the reclamation recovery that should be the responsibility of the PETI. Holders of mining business permits shall carry out environmental management and monitoring as well as post-mining reclamation undertaken in accordance with an approved environmental impact as sessment.

The signing of Law no. 32 of 2009 on Protection and Management of Living Environment as a complement to the previous legislation that is Law No.23 of 1997 is nothing but management of the Environment, not for prohibiting the existence of mining activities in Indonesia.

The idea of Environmental Law is in fact progressive so that development and industries are controlled, planned to become sustainable. Therefore, in Law No.32 of 2009 Article 1 Paragraph 3 which states that sustainable development is a conscious and planned effort that combines aspects of the environment and the safety, abilities, welfare and quality of life of present and future generations.

The main legal problems in coal mining in South Kalimantan (kalsel) is the reality that the environment around the mines gets progressively more damaged. While in an official report from the local government that the law has been well implemented and guaranteed no issues with environmental damage because based on company reports there is always reclamation of mining area.

A review of Article 33 of the 1945 Constitution has always been buzzing and found to be the bas is of mining management in Indonesia. Article 33 Paragraph 3 of the 1945 Constitution outlines that natural resources, including land and water are controlled by the State and should be utilized in order to maximally benefit the people. So based on this then the management of natural resources must start from the side of the State's power over the natural resources towards the most prosperity for the people.
Mining activities are activities with temporary land use, which take place as long as the ore or valuable materials to be mined are still available and still have economic value to extract. In case the ore or material reserves have been exhausted then the mine closure is done.

In South Kalimantan, generally coal mining is done by open pit mining. This open mining has a negative influence on the environment such as: the disappearance of the hills, the dams and the changes of river water flow, deforestation and the formation of holes in which can reach many tens of meters. Meanwhile, other changes to the gradual environment are the decline of the groundwater surface with all the consequences of crop destruction and reduced soil fertility and increased erosion. Mining activities may cause irreversible damage.

Article 1 number 26 Reclamation is on activites undertaken throughout the stages of mining companies' obligations to restore ex-mining areas to be regulated in various laws, namely: Law No. 4 on Mining Minerals and Coal mining enterprises to organize to restore and improve the quality of the environment and ecosystemin order to function again according to its designation.

In Law No.4 of 2009 on Mining Minerals and Coal mining efforts to organize, restore and improve the quality of the environment and ecosystems in order to function again according to its designation.

In the juridical perceptive of the obligation of applying good mining technical principles such as management and monitoring of mining environment, including reclamation and post mining activities. Reclamation activities are activities aimed at improving or managing disrupted land use as a result of general mining business activities in order to be functional and efficient according to their allocation. It indicates that the coal mining concession is less or not executed in accordance with the legislation that regulates it, namely Law of PPLH (Protection and management of the environment) and Minerba Act and all its implementation regulations.

From the description above the following problems are:

1. What is the environmental impact of coal mining in South Kalimantan, especially for unlicensed mining business activities?

2. How is the environmental management and progressive law on reclaimed coal mines?

\section{RESEARCH METHODS}

Starting from the background of the problem and in order to realize the objectives of the research to be achieved, then the type of research is normative legal research with starting point at the legislation that is closely related to mining law on the reclamation of coal mining. This research is descriptive and prescriptive. The legal substances used in this study include primary, secondary and tertiary legal materials.

\section{DISCUSSION}

Theoretically, according to Abrar, the engagement of the State in the mining sector includes three aspects:

1. Regulatory Aspects

2. Aspects of Operation (taking care of)

3. Aspects of supervision [5]

This regulatory aspect is an absolute right of a state that should not be left to the private sector and the most important 
aspect of state engagement. The role and dominance of the state in the regulatory aspect aims to determine and regulate the institutional structure of patterns of relations between government, economic actors and the people as a whole in the field of economy.

\section{A. Environmental Impacts on coal mining without permits.}

Mining activities spent a considerable amount of energy in the form of fuel, this energy used for mining material trans port from mining location to processing place. In underground mines, the transport of material to the surface, air vents and hole temperature control up to the ore terminal are consuming enormous energy. Overall it eventually releases $\mathrm{CO} 2$ which contributes to global warming. In addition, mining activities have an effect on air quality. Starting from the blasting events, the operational trucks are transported on open land, uncovered tailing dams. All that has released dust into the air. And a number of radioactive elements present in the ore can cause radiation. Smelters that operate by ignoring work safety cause the release of heavy metals bound to sulfide into the air. Acid rain and smog are also often the effect of mining activities.

\section{B. Impact on water}

Mining activities have a lot of water use although some are the result of recirculation. Sulfide-containing minerals, due to their contact with air, form sulfide acids in combination with trace elements. This condition, in its entirety, has a negative impact on both surface and ground water. Water pollution can also come from piles of coal or coal waste, not to mention the explosion process that can raise water salinity.

In gold extraction activities, a number of toxins such as cyanide and mercury can permanently contaminate the water. Both are commonly used in mines that extract primary gold, which is the formation of gold as sociated with mineralization or magmatic processes. In this type of mining is more easily found the impact of both toxins on a number of living things.

\section{Impact on health and safety}

In the underground mine the possibility of accidents is greater than the surface mine due to lighting factors, air ventilation and the danger of rock falls. The biggest health risk is the presence of dust that can cause problems (Silicosis). In addition, there is also the possibility of radiation effects from radioactive elements. Developing countries, often victims of mining activities due to contamination of clean water sources.

As mandated by Article 101 of Law No. 4 of 2009 concerning Minerba on December 20, 2010, the government issued Government Regulation Number 78 Year of 2010 on Reclamation and Post-mining detailing matters relating to reclamation and post-mining obligations, listed simply in articles 99-100 of Law Number 4 Year of 2009.

\section{ENVIRONMENT AL MANAGEMENT AND PROGRESSIVE LAW IN MINING RECLAMATION}

Law No. 4 of 2009 on Minerals and Coal still legalizes coal dredging. This law deals with environmental laws and forest laws or umbrella provision for other legislative bodies.

Noting what is contained in Article 2 of Law No.4 Year of 2009, the principles and objectives mentioned that the mineral or coal mines are managed based on:

a. Benefit, fairness and equilibrium

b. Partiality to the nation

c. Participatory, transparent and accountable

\section{d. Sustainable and environmentally sound.}

In fact until now with the issuance of Law No.4 of 2009 it is still felt that the dredging of coal does not meet on the environment, namely forest destruction and reclamation that failed. The forestry minister has warned mining companies to pay attention to the environment in south Kalimantan. For that is not to be over-exploited, because it will harm the environment in the future. The warning of the forestry minister is very severe, this is because the Coal Minerals Law has granted extensive permits in accordance with what procedures it regulates. The regulation has generally supported dredging, even though in the principle of regulatory purposes it calls pro on benefits, equity, national interests and environmental insight. Yet mining is still felt now strongly supporting the occurrence of destruction as happened in south kalimantan and other forest areas in Indonesia. South Kalimantan's wealth is now completely depleted. The regulation of the new order era has depleted the forests of southern Kalimantan and is now dredging the earth with the rise of coal mining, besides the riches of other earths such as iron ore, manganese, gold, kaolin, quartz sand, limestone, phosphate, chiromite, nickel and others.

The local government of South Kalimantan claims a large proportional to the province of South Kalimantan, the area which has been opened for mining activities is $0.23 \%$. This means that licensing of coal is still considered small, but a valid comparis on is to look at forest areas. Some valid data on environmental reality in the south of the country each year shows increasingly deteriorating environmental conditions. South Kalimantan has lost its forest as a protector of life. Evidenced by severe damage to the forest that has an impact on the deterioration of the quality of human resources, the destruction of infrastructure, the loss of tribal rights and smallholdings, floods, the lack of local revenue and poverty. The destruction of the environment will have an impact on increasing poverty.

Reclamation that has been voiced in legal regulation is not sufficient to improve the environment. The destruction of forest resources and the dredging of coal in South Kalimantan can not be avoided and felt directly by most of the people. Right now someone is looking over the mine area like a black desert accompanied by a big hole in the bottom. There is no possibility to be reclaimed because the holes are so large and very deep. At its core is not only a matter of the structure of law, but also in the area of legal substance that is still perceived as less unders tood by officials and law enforcement. So many weaknesses that exist in Law no. 4 year of 009 about coal minerals is not accompanied by progressive thinking. One of them is the sanction in which only the company can be snared only administratively. While the unauthorized part of the people dredge the land even with simple tools, it can be charged with a penal sanction of up to 10 years. In other words, the law is seen in favor of a strong man who all have relied on their big companies to dredge mining.

It can not be denied that mining activities can cause irreversible damages. Once an area is opened for mining operation, then the area will potentially be damaged forever. In order to restore the condition of the land in such a way that it can be functional and efficient according to its allocation, then to the former mining land, in addition to the closure of the mine, also must be done recovery of the former mining area. 
Article 1, paragraph 26, reclamation shall be activities carried out throughout the phases of mining companies' obligations to recover former mining areas undervarious laws and regulations, namely Law No. 4 of 2009 concerning Mineral and Coal Mining to establish, restore and improve the quality of the environment and the ecosystem in order to function again according to its allocation. Reclamation and post-mining activities shall be carried out with due regard to the environmental, occupational safety or health as pects of the workers, and the conservation of minerals and coal (specifically to production IUP holders.) Several points to be considered in relation to the reclamation exercise are the following:

1. Reclamation shall be done no later than 1 (one) month after cessation of mining activities on disturbed land covering:

2. Reclamation is done by a mining company in accordance with the reclamation plan, including the amendment of the reclamation plan, which has been approved by the minister, governor or regent or mayor in accordance with its authority.

The reclamation plan is prepared for the implementation of every 5 (five) years with annual details covering land use before and after mining, land clearance plan, reclamation program and reclamation cost plan.

Based on the above description, it can be concluded that the effort to restore the condition of the land in order to function in accordance with its allocation through reclamation, is not merely the responsibility of the mining company, but also the government's responsibility in this case the Minister, Governor, or even Regent or Mayor because they do the assessment and approval of the plan reclamation, as well as supervising the implementation of reclamation by mining companies.

Is sues of mineral and coal are not only to social is sues but also environmental is sues also have an impact on society in the future. The extent of licensing in the coal mineral law is very dependent on the conscience of the regional head. This reality also during this time in south kalimantan which creates negative impact and critical of forest and earth of south Kalimantan. There has been no significant settlement to the mining problem so far, except for the worsening environmental damage. Therefore, it is necessary to understand and revise the substance of law, especially Law No.4 Year of 2009 on Mineral Coal as well as the way of thinking of authorized officials as well as mining business actors. A pro-progressive way to the people as well as regional policies that should also be pro-people.

According to Lily Rasjidi, positive national law that can be used for community renewal still needs improvement and development [6].

According to Satjipto Raharjo, the law is only seen as a regulation of procedures attached to power. Though behind the law is also loaded with value, the idea that it became a particular [7]. His view requires that legal content be broad enough in morality. Formal procedures may not necessarily lead to the properimplementation of the law to its purpose. In fact, it could have pushed for an action that was not entirely legal. Therefore, the law substance must also be unders toodso that the humanitarian areas are not disturbed. The size of the substance of the law is not only in the intent of legislation, but also broader into pro-people justice.

\section{CONCLUSION}

Based on the description above, it can be concluded as follows:

1. Coal mining has largely covered all the mining of the forests of Southern Kalimantan (open pit mining) along the Meratus mountains having adverse effects on the natural environment (already very severe) and has created a bad environment for health, degradation of human resources quality, infrastructure damage, the loss of tribal lands, destruction of people's plantations, poverty, the main cause of floods and environmental problems that are sustainable.

2. Coal mining in south Kalimantan does not reflect the implementation of progressive law of the environment and there is no legal awareness about coal mining reclamation as well as there is no government controlling factor to ensure the implementation of post-mining reclamation. They only take the advantageous aspects of the region against Law no. 4 of 2009 on coal minerals without Law based on environmental management such as Law No.32 of 2009, Law No.26 Year 2007 on Spatial Planning, Law No.5 of 1990 on Conservation of Biological Resources and Ecosystem and Law No.41 of 1999 on Forestry.

\section{Suggestion}

1. The environmental impacts caused by coal mining can be reduced by the socialization of progressive lawbased environmental law. It teaches an awareness that the lack of environmental preservation is the main problem of all the formal legality that negatively impacts the environment and society. Therefore, it is advisable that in the implementation of Law No. 4 of 2009 still prioritize the environmental law as umbrella provision for other legislation. The South Kalimantan government should also try new alternatives to develop non excavated sectors as the main regional income (Agriculture or development of a small economic community in producing goods).

2. The need for increased legal awareness about the reclamation of coal mining to all parties concerned and the supervision of the government to ensure the implementation of post-coal mining reclamation .

\section{REFERENCES}

[1] A. Fauzi, Natural Resources and Environment Economics. Theory and ... Application. Jakarta: PT.Gramedia PustakaUtama, 2010. p.98

[2] M. D. Silalahi, Environmental Law In Indonesia 's Environmental Law Enforcemen System. Bandung: PT Alumni, 2011, p.98.

[3] B. P. Soedarso, "Portrait of Mining Law in Indonesia Under the Era of Law No.4 Year 2009.," J. Int. Law, vol. 6, no. 3, 2009, p.411.

[4] P. W. C. (PWS), Invites New Investment in the field of Mining, World Bank. Jakarta: Indonesian Journal Policy Briefs, 2003.

[5] Abrar, "State Title of Mining Based on Mining The 1945 Constitution," Padjadjaran University Bandung, 1999, p. 181.

[6] L. Rasjidi, "Legal Role in Indonesian National Development in Responsive Law," J. Alignment Law Rev., vol. 1, no. 1, 2005, p.

[7] S. Rahardjo, Uncovering Progressive Law. Jakarta: Kompas Publishing, 2008, pp. 253-254. 